\begin{tabular}{|c|c|c|c|c|}
\hline JURNAL & \multirow{2}{*}{ NOLUME 2 } & NOMOR 2 & HALAMAN 111-119 & $\begin{array}{l}\text { ISSN 2655-8823 }(p) \\
\text { ISSN 2656-1786 }(e)\end{array}$ \\
\hline
\end{tabular}

\title{
DAMPAK PANDEMI COVID-19 TERHADAP KEKERASAN DALAM RUMAH TANGGA
}

\author{
Theresia Vania Radhitya \\ Program Studi Ilmu Kesejahteraan Sosial FISIP - Universitas PadjadjaranDepartemen \\ E-mail: theresia17001@mail.unpad.ac.id \\ Nunung Nurwati \\ Departemen Kesejahteraan Sosial FISIP Universitas Padjadjaran \\ E-mail: nngnurwati@gmail.com \\ Maulana Irfan \\ Departemen Kesejahteraan Sosial FISIP Universitas Padjadjaran \\ E-mail: maulana.irfan@unpad.ac.id
}

\begin{abstract}
ABSTRAK
Pandemi COVID-19 yang terjadi di Indonesia sebagai akibat meluasnya penyebaran virus di tingkat dunia memaksa Pemerinta Republik Indonesia untuk melakukan berbagai kebijakan. Kebijakan ini dikeluarkan untuk menekan jumlah korban yang terjangkit virus corona. Penyebaran COVID-19 melalui droplet dan kontak fisik membuat adanya penerapan social distancing dan karantina mandiri di rumah sehingga menyebabkan masyarakat harus tinggal di rumah setiap harinya. Dilema penerapan ini membawa konsekuensi pada berbagai aspek. Di satu sisi penerapan sosial distancing memberi dampak positif pada bidang kesehatan untuk menekan jumlah penduduk yang menjadi korban virus corona, di lain sisi dampak negatif muncul pada bidang perekonomian karena sulitnya masyarakat untuk bekerja atau mencari penghasilan. Secara sosial, tidak menutup kemungkinan persoalan rumh tangga juga muncul sebagai akibat kebijakan social distancing yang mengharuskan masyarakat untuk tetap berada di rumah atau tidak melakukan aktifitas di luar rumah jika dirasa tidak penting. Salah satu masalah sosial yang terjadi di masyarakat diantaranya adalah adanya kekerasan dalam rumah tangga. Metode penelitian yang disajikan dalam artikel ini menggunakan studi literature, dengan menggunakan berbagai sumber data yang diperoleh dari beberapa jurnal, buku, maupun berita terkait dengan isu-isu kekerasan dalam rumah tangga, dan hubungan diantara keduanya. Tujuan dari artikel ini untuk mendeskripsikan persoalan yang terdampak dari pandemic COVID-19, secara khusus masalah sosial yang terjadi dalam kehidupan keluarga yaitu kekerasan dalam rumah tangga, sebagai akibat dari adanya penerapan Social Distancing.
\end{abstract}

Kata Kunci : Kekerasan Dalam Rumah Tangga, Konflik, Pandemi COVID-19, Social Distancing.

\section{PENDAHULUAN}

Saat ini di seluruh belahan dunia sedang mengalami fenomena pandemi COVID-19 atau dikenal juga dengan sebutan virus corona. Pandemi merupakan sebuah epidemi yang menyebar ke beberapa negara atau benua, dan pada umumnya menjangkiti banyak orang. Pada tanggal 11 Maret 2020, WHO menetapkan COVID-19 sebagai sebuah pandemi. Pada tanggal 13 April 2020 berdasarkan data Worldometers (diambil dari Rossa \& Putri, 2020), jumlah kasus dari virus ini di dunia sudah mencapai angka 1.856 .800 pasien yang positif corona sedangkan angka kematian pasien positif COVID-19 secara global telah menyentuh angka 114.312 jiwa dan pasien yang berhasil sembuh 428.275 orang. Dalam hal ini beberapa negara melakukan berbagai upaya untuk menghentikan virus ini. Upaya yang dilakukan pemerintah sangat mempengaruhi aktivitas masyarakat di negara yang terjangkit. Terlebih Hal ini terjadi karena penyebaran COVID-19 terjadi melalui kontak antar sesama yang menyebabkan perlunya social distancing untuk diterapkan di masyarakat. Adanya social distancing ini membuat berkurangnya aktivitas bersama dengan orang lain. Selain itu beberapa negara juga menghimbau masyarakatnya untuk tetap 
tinggal di rumah dan tidak beraktivitas diluar rumah.

Penerapan social distancing dan tetap tinggal di rumah juga berlaku di Indonesia. Hal ini dikarenakan meningkatnya jumlah kasus positif corona di Indonesia. Berdasarkan data dari Gugus Tugas (dikutip dari Idhom, 2020) pada tanggal 23 April 2013 tercatat jumlah kasus positif COVID-19 mencapai 4.557 dimana sebanyak 3.778 pasien masih dalam proses perawatan dan total angka kematian mencapai 399 jiwa. Saat ini juga mulai diberlakukan PSBB pada beberapa daerah yang dibuat dalam rangka pencegahan penyebaran corona di Indonesia. PSBB adalah Pembatasan Sosial Berskala Besar. Aturan PSBB ini sudah tercatat dalam Peraturan Menteri Kesehatan Nomor 9 Tahun 2020. PSBB menyebabkan terganggunya aktivitas masyarakat seharihari karena pembatasan ini meliputi peliburan sekolah dan tempat kerja, pembatasan kegiatan keagamaan, pembatasan kegiatan di tempat atau fasilitas umum, pembatasan kegiatan sosial budaya, transportasi, dan pembatasan kegiatan lainnya. Masyarakat pun saat ini banyak menghabiskan waktu di rumah. Bagi beberapa orang mungkin menghabiskan waktu di rumah adalah aktivitas yang menyenangkan karena rumah merupakan tempat kita merasa aman namun bagi beberapa orang tidak.

Adanya permasalahan KDRT membuat beberapa orang tidak suka untuk menghabiskan waktu di rumah namun saat ini mereka harus berdiam diri di rumah. Menurut penuturan Sekjen PBB Antonio Guteres (dikutip dari Awaliyah \& Rostanti, 2020) bahwa terdapat kekhawatiran atas naiknya KDRT di beberapa negara dimana hal ini dikarenakan banyak orang yang terperangkap di rumah dengan pasangan yang kasar. Seperti yang dikatakan Sekjen PBB Antonio Guteres, beberapa negara yang dikabarkan memiliki angka KDRT yang meningkat antara lain Australia, China, Spanyol, dan Indonesia. Di China tercatat 300 pasangan mengajukan cerai sejak 24 Februari 2020 dimana sejak diterapkan lockdown, perceraian ini dikarenakan sering terjadi pertengkaran yang dapat berujung pada KDRT. Lalu di Spanyol, terdapat aduan 18 persen lebih banyak di dua minggu pertama lockdown diberlakukan. Selama pandemi COVID-19 di Australia terjadi peningkatan sebanyak sepertiga kasus dari 40 persen jumlah klien korban KDRT.

Terdapat faktor-faktor yang menyebabkan KDRT selama pandemi COVID-19 ini seperti faktor sosial, ekonomi, dsb. Faktor ekonomi menjadi penyebab yang paling utama saat pandemi covid-19 ini karena aktivitas ekonomi juga berkurang bahkan terhenti. Banyak terjadi Pemutus Hubungan Kerja (PHK) sehingga ekonomi keluarga yang di PHK mengalami tidak adanya pemasukan untuk membiayai hidup sehari-hari. Dari masalah tersebut maka dapat memicu tekanan dan menyebabkan emosi berlebih pada pencari nafkah yang dapat berujung pada kekerasan fisik. Di Indonesia sendiri kasus KDRT di Jogja juga meningkat (www.harianjogja.com, diunduh pada tanggal 14 April 2020 pukul 20.00) . Kepala Dinas Pemberdayaan Masyarakat Perempuan dan Perlindungan Anak (DPMPPA) Jogja, Edy Muhammad, menjelaskan pada Maret terjadi 18 kasus kekerasan dengan korban perempuan sebanyak 14 orang dan laki-laki sebanyak 4 orang. Selain itu juga terjadi korban kekerasan pada Anak pada Maret berdasarkan data dari Pusat Pelayanan Terpadu Pemberdayaan Perempuan dan Anak (P2TP2A) Kota Jogja (www.tribunjogja.com, diunduh pada tanggal 14 April pukul 20.10). Angka KDRT pada bulan Maret meningkat jika dibandingkan dua bulan yang lalu, Januari dan Februari. Menurut pernyataan Tuani Sondang Rejeki Marpaun (www.tempo.co, diunduh pada tanggal 14 April pukul 20.20), anggota Lembaga Bantuan Hukum Asosiasi Perempuan Indonesia untuk Keadilan (LBH Apik), pada tanggal 16 Maret sampai 12 April tercatat terdapat 75 


\begin{tabular}{|c|c|c|c|c|}
\hline JURNAL & \multirow{2}{*}{ VOLUME 2 } & NOMOR 2 & HALAMAN 111-119 & $\begin{array}{l}\text { ISSN 2655-8823 }(p) \\
\text { ISSN 2656-1786 }(e)\end{array}$ \\
\hline
\end{tabular}

pengaduan kasus. Kasus KDRT berada di peringkat kedua berdasarkan pengaduan kasus tersebut.

\section{METODE PENELITIAN}

Metode yang digunakan untuk melihat dampak dari COVID-19 pada Kekerasan Dalam Rumah Tangga adalah dengan melakukan metode studi literature. Studi literature ini diambil dari beberapa jurnal, buku, maupun berita terkait dengan isu-isu kekerasan dalam rumah tangga, pandemic COVID-19 dan hubungan diantara keduanya.

\section{Pandemi Virus COVID-19}

Menurut Kamus Besar Bahasa Indonesia (Https://kbbi.web.id/pandemi, diunduh pada tanggal 14 April 2020 pukul 19.30), pandemic merupakan wabah yang berjangkit serempak di mana-mana, meliputi daerah geografi yang luas. Michael Ryan, Direktur Eksekutif Program Keadaan Darurat Kesehatan WHO menyatakan bahwa kata pandemic berasal dari kata Yunani yaitu, pandemos berarti "semua orang". Pandemos merupakan sebuah konsep kepercayaan bahwa populasi seluruh dunia kemungkinan akan terkena infeksi dan sebagian besar akan jatuh sakit. WHO dalam memberikan status pandemi berlandaskan pada beberapa fase. Beberapa fase suatu penyakit dinyatakan sebagai suatu pandemic antara lain: (1) Fase 1, dimana tidak terdapat virus yang beredar di antara hewan dapat menyebabkan infeksi pada manusia; (2) Fase 2 ditandai adanya virus yang beredar pada hewan yang diketahui dapat menyebabkan infeksi pada manusia sehingga dianggap sebagai potensi ancaman pandemi; (3) Fase 3 dimana virus yang disebabkan dari hewan menyebabkan beberapa kasus secara sporadis atau menjangkiti sekelompok kecil orang. Penularan dari manusia ke manusia masih terbatas; (4) Fase 4, fase ini terjadi penularan virus dari manusia ke manusia atau hewan ke manusia yang bertambah banyak sehingga menyebabkan terjadi wabah; (5) Fase 5, dimana penyebaran virus dari manusia ke manusia terjadi setidaknya pada dua negara di satu wilayah WHO; dan (6) Fase 6 dimana fase ditandai dengan wabah semakin meluas ke berbagai negara di wilayah WHO. Fase ini menunjukkan bahwa pandemic global berlangsung.

Virus COVID-19 disahkan statusnya menjadi pandemi oleh WHO pada tanggal 11 Maret 2020. Hal ini dikarenakan penyebaran dari virus COVID-19 semakin meningkat dan sudah menyebar ke 114 negara. Virus corona atau dalam bahasa medis disebut severe acute respiratory syndrome coronavirus 2(SARS-CoV-2) merupakan virus yang menyerang sistem perapasan, pneumonia akut, hingga kematian. Virus ini dapat menyerang setiap orang tidak mengenal usia mulai dari bayi, anak-anak, orang dewasa, lansia, ibu hamil, dan juga ibu menyusui. Pada Desember 2019, virus ini pertama kali ditemukan tepatnya di Kota Wuhan, Cina dan menyebar ke wilayah lain dan beberapa negara (Pane, 2020).

Berdasarkan sebuah artikel (Pane, 2020), gejala virus ini berupa gejala flu, demam, pilek, batuk kering, sakit tenggorokan, dan sakit kepala. Selain itu dapat mengalami demam tinggi, batuk berdahak, sesak napas, dan nyeri dada. Virus ini dapat tertular melalui berbagai cara seperti, tidak sengaja menghirup percikan ludah yang keluar saat penderita batuk dan bersin, memegang mulut atau hidung tanpa mencuci tangan setelah menyentuh benda yang terkena droplet penderita, dan kontak jarak dekat dengan penderita seperti bersentuhan atau berjabat tangan.

\section{Kekerasan Dalam Rumah Tangga}

Dalam Kamus Besar Bahasa Indonesia, "kekerasan" diartikan sebagai hal yang sifatnya berciri keras, perbuatan seseorang yang akan menyebabkan cedera atau meninggalnya orang lain atau menyebabkan kerusakan fisik. Dalam 
Undang-Undang Nomor 23 Tahun 2004 Pasal 1 menyebutkan Kekerasan Dalam Rumah Tangga merupakan seriap perbuatan terhadap seseorang terutama perempuan, yang berakibat timbulnya kesengsaraan atau penderitaan secara fisik, seksual, psikologis, dan/atau penelantaran rumah tangga termasuk ancaman untuk melakukan perbuatan, pemaksaan atau perampasan kemerdekaan secara melawan hukum dan lingkup rumah tangga.

Menurut Undang-Undang No. 23 Tahun 2004 Tentang Penghapusan Kekerasan Dalam Rumah Tangga, bentuk kekerasan dalam rumah tangga, yaitu: (1) Kekerasan Fisik, dimana bentuk ini merupakan perbuatan yang mengakibatkan rasa sakit, jatuh sakit atau luka berat. Dalam konteks relasi personal, bentukbentuk kekerasan fisik antara lain tamparan, pemukulan, penjambakan, penginjak-injakan, penendangan, pencekikan, lemparan benda keras, penyiksaan menggunakan benda tajam, seperti pisau, gunting, setrika serta pembakaran.; (2) Kekerasan Psikis, dimana kekerasan ini merupakan perbuatan yang mengakibatkan ketakutan, hilangnya rasa percaya diri, hilangnya kemampuan untuk bertindak, rasa tidak berdaya, dan atau penderitaan psikis berat pada seseorang. Bentuk kekerasan secara psikologis yang dialami berupa makian, penghinaan berkelanjutan untuk mengecilkan harga diri korban, bentakan dan ancaman yang diberikan untuk memunculkan rasa takut. ; (3) Kekerasan seksual, dimana kekerasan ini merupakan pemaksaan hubungan seksual yang dilakukan terhadap orang yang menetap dalam rumah tangga atau pemaksaan hubungan seksual pada salah seorang dalam lingkup rumah tangganya dengan orang lain untuk tujuan komersial dan tujuan tertentu.; (4) Penelantaraan Rumah tangga, kekerasan ini berupa tindakan seseorang yang tidak melaksanakan kewajiban hukumnya pada orang dalam lingkup rumah tangga berupa mengabaikan dalam memberikan kewajiban kehidupan, perawatan atau pemeliharaan pada orang tersebut

\section{Penyebab Kekerasan Dalam Rumah Tangga}

Korban dari Kekerasan Dalam Rumah Tangga mayoritas adalah perempuan dan anak. Menurut Kramarae \& Treichler (1991), kekuatan patriakal yang ada karena adanya budaya serta nilai dari masyarakat membuat perempuan menjadi korban dalam kekerasan domestik. Di Indonesia beberapa masyarakat masih memegang teguh kekuatan patriakal dalam menjalankan kehidupan berumahtangga. Menurut Foucault (1997), laki-laki di dalam kehidupan sudah terbentuk menjadi pemiliki "kuasa" dimana mereka menentukan arah di masyarakat. Hubungan laki-laki dengan perempuan di Indonesia dilihat secara sosio-kulttural terbangun melalui beberapa alasan diantaranya: (a) Fisik laki-laki lebih kuat jika dibandingkan dengan perempuan serta kemungkinan besar tingkat agresivitas dari laki-laki juga tinggi jika dilihat dari dasar biologis. Laki-laki di dalam kehidupan bermasyarakat sering melatih menggunakan fisik, senjata, dan intimidasi kekuatan sejak kecil.; (b) Masyarakat memiliki tradisi mengenai dominasi lakilaki pada perempuan dan lebih toleransi jika laki-laki menggunakan kekuatan. Tradisi ini dapat kita lihat melalui adanya film, pornografi, musik, dan media lainnya.; (c) adanya realitas ekonomi dimana perempuan harus menerima penganiyaan dari orang yang mnjadi tempat menggantungkan hidupnya. ; (d) sebagian laki-laki melakukan kekerasan dan sebagian perempuan selain itu sebagian laki-laki tidak melakukan kekerasan dan sebagain perempuan juga tidak menjadi sasaran dalam kekerasan; (e) kesimpulannya adalah terdapat suatu perbedaan kekuatan dan kekuasaan pada perempuan dan laki-laki dimana dalam hal ini dipersepsikan sebagai suatu hak dan kemampuan dalam melakukan tindakan pengendalian satu sama lain. 


\begin{tabular}{|c|c|c|c|c|}
\hline JURNAL & \multirow{2}{*}{ VOLUME 2 } & NOMOR 2 & HALAMAN 111-119 & $\begin{array}{l}\text { ISSN 2655-8823 }(p) \\
\text { ISSN 2656-1786 }(e)\end{array}$ \\
\hline
\end{tabular}

Perempuan memiliki sifat nature dimana sifat ini memiliki hubungan timbal balik dengan alam dikarenakan sifat yang produktif serta kreatif (Humm, 1990) sedangkan laki-laki identik dengan mengeploitasi alam. Laki-laki dan perempuan memiliki peran yang berbeda satu sama lain. Perbedaan ini dikarenakan adanya perbedaan bologis. Perbedaan peran dapat dilihat dari teori nurture dimana perbedaan merupakan hasil dari konstruksi budaya dan masyarakat yang menempatkan laki-laki unggul dari perempuan. Di masyarakat perempuan dilihat sebagai seseorang yang tidak memilki kekuatan fisik, lemah, emosional dan hanya berhakmengerjakan pekerjaan yang halus diantaranya pekerjaan rumah, melakukan pengasuhan pada anak, dan lain-lain. Dengan begitu maka muncullah kekerasan dalam rumah tangga karena adanya anggapan masyarakat tersebut.

Selain itu secara umum penyebab terjadinya kekerasan dalam rumah tangga oleh suami terhadap isteri disebabkan karena:

\section{Faktor Intern}

a. Motivasi

b. Kebutuhan hidup manusia, dimana kebutuhan ini berkaitan dengan upaya manusia dalam mempertahankan dan mengembangkan kehidupannya dimana disebabkan karena adanya kebutuhan hidup manusia terutama biologis yang menjadi kebutuhan primer.

c. Minat.

d. Kejiwaan dimana berpengaruh pada tindakan yang dilakukan, tindakan tersebut dapat dilihat dari perspektif berbeda dimana menurut orang lain tindakan itu bukanlah tindakan yang baik.

\section{Faktor Ekstern}

a. Faktor Ekonomi keluarga, dimana pengaruh yang diberikan dari faktor ini bisa berupa pengaruh positif maupun negatif terhadap kondisi rumah tangga. Perekonomian dapat memicu adanya pertengkaran dalam rumah tangga apabila perekonomian dalam keluarga berkurang.

b. Faktor Lingkungan Sosial, dimana kondisi terjadi dengan baik dan mempengaruhi hal-hal yang ada dalam diri manusia.

c. Faktor Pandangan Masyarakat dimana masyarakat menganggap bahwa laki-laki lebih dominan dan memilki kedudukan tinggi jika dibandingkan dengan perempuan. Selain itu juga memposisikan perempuan dan laki-laki secara berbeda.

\section{Dampak Kekerasan Dalam Rumah Tangga}

Menurut Santoso (2019), dampak dari kekerasan dalam rumah tangga bagi perempuan dapat dibendakan menjadi 2, yaitu dampak jangka pendek dan dampak jangka panjang. Dampak jangka pendek berdampak secara langsung dan biasanya mempengaruhi fisik contohnya luka fisik, cacat, kehamilan dan terkadang juga hilangnya pekerjaan. Lalu dampak jangka panjang berkaitan dengan psikis dimana korban akan mengalami gangguan psikis, rasa kurang percaya diri, mengurung diri, trauma dan muncul rasa takut hingga depresi. Selain itu juga terdapat dampak dari kekerasan terhadap anak sebagai korban dimana menurut Viqa ( dalam Prajatami, Raharjo, Hidayat, \& S, 2016) dampaknya antara lain:

1. Dampak fisik, dimana meninggalkan perubahan bentuk fisik seperti leban dipermukaan kulit, benjol, adanya luka bahkan patah tulang.

2. Dampak Psikis dimana kekerasan menimbulkan gangguan jiwa. anak dapat memilki kepercayaan diri yang rendah dan mengalami 
ketakutan serta kecemasan. Selain itu dalam melakukan interaksi sosial mereka juga kurang terbuka dan berbaur dengan lingkungan sosialnya.

3. Dampak seksual, dimana anak dalam hal ini dapat terinfeksi penyakit seksual yang menular, gangguan reproduksi, dan apabila parah dapat tidak memiliki keturunan.

4. Dampak Sosial, dimana adanya perlakuan yang diterima oleh anak korban kekerasan membuat mereka sulit untuk tumbah dan berkembang dengan baik. Anak akan memiliki kecenderungan untuk melakukan perilaku yang menyimpang serta menutup diri. Mereka bahkan dapat membalas dan menyakiti diri sendiri serta orang sekitar untuk melampiaskan perasaan atau trauma yang mereka dapatkan dari kekerasan yang diterima.

\section{Dampak COVID-19 pada Kasus Kekerasan Dalam Rumah Tangga}

Adanya fenomena COVID-19 saat ini memberikan beberapa dampak bagi masyarakat. Dampak yang ditimbulkan dari COVID-19 bermacam-macam mulai dari dampak ekonomi hingga sosial. Hal ini dikarenakan juga adanya beberapa kebijakan yang dibuat oleh pemerintah dalam upaya mengurangi penulan yang terjadi di masyarakat. Penularan virus COVID-19 melalui droplet atau kontak fisik membuat pemerintah mengeluarkan kebijakan social distancing dan karantina menghimbau masyarakat untuk tetap tinggal di rumah dan tidak pergi kemanamana.

Adanya masa karantina membuat angka kekerasan dalam rumah tangga terhadap perempuan serta anak meningkat secara global. Hal ini terjadi karena banyaknya perempuan yang terpaksa melakukan isolasi atau "terisolasi" di rumah dengan pelaku tindak kekerasan. Dian Kartikasari, Ketua Dewan Pengurus INFID dan Sekjen Koalisi Perempuan Indonesia (KPI) 2009-2020 menyatakan masa isolasi mandiri berpengaruh dalam menciptakan adanya konflik di dalam rumah tangga. Kasus kekerasan yang dialami oleh perempuan saat ini beragam mulai dari kekerasan fisik, psikis, dan seksual. Kasus yang dialami oleh perempuan kepala keluarga salah satunya adalah percobaan perkosaan saat berlangsung penyemprotan disinfektan.

Keadaan terisolasi juga berisiko dimana individu akan mengalami PTSD, depresi, kecemasan, dan kesehatan mental lainnya. John Gottman (dalam Gottman \& Declaire, 1998) menyatakan bahwa pelaku KDRT terbagi menjadi dua yaitu, Characterlogical dan Situational. Situational ini dapat menjadi penyebab KDRT ditengah-tengah masa seperti sekarang dikarenakan mengalami stress yang diakibatkan tinggal di rumah terus menerus, stress dikarenakan kehilangan pekerjaan, pendapatan berkurang serta isu lain.

Selain keadaan terisolasi, kondisi perekonomian dalam keluarga selama masa pandemi ini juga menjadi penyebab dari meningkatknya KDRT. Adanya pandemic COVID-19 ini membuat beberapa karyawan di Indonesia terancam dari pemberhentian hak kerja (PHK) dikarenakanan banyaknya pekerjaan yang tidak memungkingkan untuk dikerjakan saat berada di rumah seperti kegiatan produksi. Selain itu PHK juga dilakukan karena kurangnya pembelian dari konsumen dan adanya pembatasan ekspor ke negara tertentu yang berujung pada berkurangnya pendapataan perusahaan yang diikuti dengan kerugian. PHK membuat masyarakat Indonesia yang bekerja dan mengalami PHK akan mengalami kekurangan dalam tingkat perekonomian rumah tangga. Hal ini akan memicu stress dan emosi karena memikirkan biaya hidup sehari-hari. Pria 


\begin{tabular}{|c|c|c|c|c|}
\hline JURNAL & \multirow{2}{*}{ VOLUME 2 } & NOMOR 2 & HALAMAN 111-119 & $\begin{array}{l}\text { ISSN 2655-8823 }(p) \\
\text { ISSN 2656-1786 }(e)\end{array}$ \\
\hline
\end{tabular}

pencari nafkah dapat melampiaskan rasa stress dan emosi serta frustasi mereka pada wanita dan anaknya dalam bentuk kekerasan. Menurut American Psychological Association (diambil dari Azmi \& dr. Goentoro, 2020), peningkatan stress yang terjadi di kalangan orangtua berujung pada pelecehan fisik dan menelantarakan anaknya. Dengan keadaan seperti ini juga orangtua merasa tertekan saat menghadapi perilaku anak di rumah dan menuntut mereka mengerjakan tugas dengan kasar atau agresif.

Adanya pemaparan diatas maka dapat disimpulkan bahwa dampak dari pandemi COVID-19 menganggu kesejahteraan keluarga dimana seharusnya keluarga memberikan dan memenuhi segala kebutuhan. Seperti yang diungkapkan BKKBN (2002), kesejahteraan keluarga merupakan suatu kondisi dinamis dimana terpenuhi semua kebutuhan : fisik materil, mental spiritual serta sosial yang memungkinkan keluarga dapat hidup wajar sesuai dengan lingkungannya serta memungkinkan seorang anak untuk tumbuh berkembang dan memperoleh perlindungan yang diperlukan sebagai upaya membentuk sikap mental serta kepribadian yang mantap dan matang sebagai sumber daya manusia yang berkualitas. Sedangkan saat ini realita yang terjadi dalam kehidupan keluarga adalah kebutuhan sosial kurang terpenuhi dikarenakan adanya social distancing yang menyebabkan tidak dapat berkomunikasi langsung dengan orang lain padahal komunikasi langsung dengan orang lain juga merupakan sebuah kebutuhan sosial. Selain itu beberapa keluarga mengalami kejadian pemutusan hubungan kerja yang mana membuat penghasilan mereka berkurang untuk memenuhi kebutuhan dan keinginan baik secara materil maupun non materil. Lalu kebutuhan dari fisik/jasmani juga sulit untuk dipenuhi dalam keluarga dengan keadaan saat ini dikarenakan tempat-tempat berekreasi tidak beropreasional dikarenakan pandemi COVID-19 yang tidak kunjung mereda.
Jika dilihat dari adanya kasus kekerasan dalam rumah tangga di masa pandemi ini maka dampaknya adalah kesejahteraan keluarga terganggu karena tidak dapat memenuhi kebutuhan secara fisik, mental spiritual, dan sosial selama pandemi COVID-19 berlangsung.

\section{Upaya Mengatasi KDRT Selama Pandemi COVID-19}

Mengatasi KDRT saat pandemic COVID-19 mungkin dirasa sulit namun terdapat beberapa hal yang dapat dilakukan untuk mengatasi KDRT. Apabila menjadi korban cara pertama untuk mengatasi KDRT adalah dengan mencari bantuan kepada orang lain atau lembaga saat menerima kekerasan. Apabila pelaku berbuat kekerasan usahakan untuk mengontrol diri agar pelaku tidak semakin terpancing untuk bertindak. KDRT dapat terjadi karena adanya faktor situasional, dengan begitu sebenarnya pelaku dan korban dapat memperbaiki kualitas hubungan yang dimiliki melalui professional atau melakukan secara mandiri dengan cara memberdayakan diri untuk membaca atau berdiskusi mengenai strategi efektif dalam menghadapi konflik. Selain itu, KDRT dapat terjadi karena adanya faktor karakter diri sendiri dimana apabila KDRT ini terjadi karena hal tersebut maka lebih baik untuk melakukan karantina diri di rumah keluarga lain.

Hal lain yang dapat dilakukan adalah melakukan sesuatu bersama-sama dengan keluarga dimana dengan melakukan kegiatan bersama akan membuat relasi atau hubungan menjadi lebih erat. Kegiatan bersama antar lain menonton televisi/film bersama di rumah lalu berolahraga bersama, dan sebagainya. Lalu apabila melakukan diskusi tidak dengan cara emosional dan lebih menghargai pendapat yang berbeda dari anggota keluarga. Apabila terjadi masalah atau konflik maka diselesaikan dengan kepala dingin dan dapat menggunakan win-win solution sehingga tidak ada yang merasa 
dirugikan dalam penyelesaian masalah. Komunikasi secara intensif juga harus dijaga, adanya komunikasi dapat membantu satu sama lain menjadi saling pengertian dan memahami diantara anggota keluarga.

\section{KESIMPULAN}

Adanya pandemi COVID-19 sangat berpengaruh dalam melakukan kegiatan sehari-hari. Selain itu juga memberikan banyak dampak bagi masyarakat mulai dari dampak kesehatan, ekonomi, dan sosial. Adanya dampak ini mempengaruhi juga munculnya permasalahan salah satunya yang terjadi saat pandemi COVID19 ini adalah masalah mengenai Kekerasan Dalam Rumah Tangga dimana sepanjang pandemi COVID-19 berlangsung terjadi peningkatan angka Kekerasan Dalam Rumah Tangga. Penyebab dari kekerasan dalam rumah tangga diantaranya karena adanya karantina di rumah secara mandiri yang membuat korban KDRT terperangkap bersama dengan pelaku KDRT. Selain itu juga memicu stress karena dengan adanya pandemi ini perekonomian keluarga menjadi berkurang yang pada akhirnya dapat memicu munculnya pertikaian keluarga yang berujung pada kekerasan.

Adanya peningkatan angka KDRT bukan hanya tugas atau tanggung jawab dari pemerintah melainkan semua lapisan masyarakat. Terdapat beberapa upaya dalam mengatasi KDRT selama masa pandemi ini dimana dapat langsung melapor kepada tugas yang berwenang. Selain itu lembaga yang mengawasi masalah ini juga harus cepat dan tanggap dalam memproses laporan mengenai KDRT dan membantu dalam menyelesaikan masalah.

\section{DAFTAR PUSTAKA}

Awaliyah, G., \& Rostanti, Q. (2020). Kasus KDRT Meningkat Selama Pandemi Covid-19. Retrieved April 14, 2020, from www.republika.co.id website: https://republika.co.id/berita/q7kv4e42 5/kasus-kdrt-meningkat-selamapandemi-covid19

Azmi, N., \& dr. Goentoro, P. L. (2020). Penyebab Meningkatnya Kasus KDRT Selama COVID-19 dan Cara Menanganinya. Retrieved from HelloSehat.com website: https://hellosehat.com/coronavirus/covi d19/kdrt-selama-pandemi/

BKKBN. (2002). Kebijakan Teknis Penanggulangan Masalah Kesehatan Reproduksi Melalui Program KB Nasional. Jakarta.

Foucault, M. (1997). Seks \& Kekuasaan: Sejarah Seksualitas. Jakarta: Gramedia. Gottman, J., \& Declaire, J. (1998). Raising An Emotionally Intelligent Child The Heart of Parenting. New York: Simon\&Schuster Paperback.

Https://kbbi.web.id/pandemi. (n.d.). Kamus Besar Bahasa Indonesia.

Humm, M. (1990). The dictionary of feminist theory. In The dictionary of feminist theory. Ohio State University Press.

Idhom, A. M. (2020). Update Corona 13 April 2020 Indonesia \& Dunia: Info Data Hari Ini. Retrieved April 14, 2020, from Tirto.id website: https://tirto.id/update-corona-13-april2020-indonesia-dunia-info-data-hariini-eMXC

Kramarae, \& Treichler. (1991). Feminist Dictionary. In The University. Boston: The University.

Pane, dr. M. D. C. (2020). Virus Corona.

Prajatami, V. N., Raharjo, S. T., Hidayat, E. N., \& S, M. B. (2016). PENANGANAN ANAK KORBAN KEKERASAN SEKSUAL.

Rossa, V., \& Putri, F. I. (2020). Update Corona Covid-19 Global 13 April 2020: Total Kasus Nyaris 2 Juta. Retrieved April 14, 2020, from suara.com website: https://www.suara.com/health/2020/04 /13/090115/update-corona-covid-1913-april-2020-total-kasus-nyaris-capai2-juta 
Santoso, A. B. (2019). Kekerasan Dalam

Rumah Tangga (KDRT) Terhadap Perempuan: Perspektif Pekerjaan Sosial. Jurnal Pengembangan Masyarakat Islam, 10.

www.harianjogja.com. (2020). Masa Sulit

Selama Pandemi Jadi Biang Melonjaknya Angka KDRT di Jogja. www.tempo.co. (2020). Di Masa Pandemi

Corona Perempuan Indonesia Lebih

\section{Rentan Alami KDRT.}

www.tribunjogja.com. (2020). Kasus

Kekerasan di Kota Yogya pada Maret 2020 Meningkat. Retrieved April 14, 2020, from tribunjogja website: https://jogja.tribunnews.com/2020/04/1 3/kasus-kekerasan-di-kota-yogyapada-maret-2020-meningkat 